\title{
Encountering globalisation: the work of Sulaiman Esa from the 1950s to 2011
}

\author{
K. Sanusi \\ Faculty of Art and Design, UiTM, Malaysia
}

\begin{abstract}
When writing about globalisation, most Asian scholars rarely fail to highlight its three inherent threats. First, its homogenising impact on non-Western culture. Second, the instantaneous global reach in communications due to technological advancement. Third, the worldwide market-driven economy which facilitates the commodification of art. Many believe that globalisation in the new millennium is increasingly pervasive and subtle in instilling Western values in non-Western countries, resulting in many conflicts. Contrary to the negative perceptions of globalisation, Sulaiman Esa, an established Malaysian artist, sees its potential for positive action. This paper has three objectives: first, to discuss the debates on the positive and negative aspects of global issues; second, to analyse Esa's dialectical involvement in responding to global challenges; third and finally, to delve into the significance of his work in the development of contemporary Malaysian art. This study is guided by both formal and informal interviews, reviews of pertinent documents, and observation. The study finds that Sulaiman Esa strikes a symbiotic balance between globalisation and his own cultural heritage, drawing on Islamic spirituality, to develop an alternative paradigm, in the development of contemporary Islamic art in the Southeast Asian region. Keywords: Malay Islamic art, globalisation, homogenisation, asserting identity, symbiotic balance, contemporary Islamic art.
\end{abstract}

\section{Introduction}

Globalisation is a concept in which people from diverse cultures are perceived as one culture community or global village (Tabb [1]). This is due to the unprecedented improvement in social mobility through better transportation systems and the explosion in communication, and information technologies 
(Annku and Adu-Agyem [2, pp. 86-91]). Such drastic developments originated in the West, and have created continuous polemics among scholars, concerning the positive and negative effects on cultures of non-Western regions, specifically on Muslim communities. However, although globalisation has many critics in non-Western societies, there is a Malaysian artist, who counters globalisation by using its positive aspects to reassert his cultural and religious identity. This paper thus has three objectives. First, a summary of the polemics concerning the positive and negatives of globalisation by both Western and non-Western scholars; second, an analysis of Esa's journey from Western-centric art to Malay Islamic art tradition; third and finally a discussion of Esa's contributions to the development of the aesthetic, social, cultural and spiritual aspects, of contemporary Malaysian art.

\subsection{Globalisation}

Globalisation is a very complex concept. As a process and a phenomenon, globalisation is both multidimensional and multiple perspectives (Nurullah [3, pp. 45-52]). While scholars have no problem in agreeing to its multidimensional scope, which includes culture, economics, politics and technology (Waters [4]), but it is concerning the direct impact it exerts on the world communities that becomes problematic. Is globalisation a boon or a bane? A promise or a predicament? Does the programs and projects initiated by global process prove injurious or beneficial to world community? These are some of the most critical and controversial issues which are still being debated and are still unresolved.

\subsection{Globalisation and its impact on non-Western cultures}

A perusal of the current writings on globalisation reveals that scholars from Western countries seem to portray this phenomenon as a dynamic process that will bring vast cultural transformation reward and benefits to the global community (Nurullah [3, p. 49]). Most non-Western scholars (especially those who had experienced Western colonisation) seem to offer contradictory viewpoints. They still harbour a lingering suspicion that globalisation is nothing more than a new strategy by the powerful Western countries to exert their cultural hegemony across the world (Vertigans and Sutton [5]; Mazrui [6]). For instance, as claimed by many Western scholars globalisation is beneficial for individuals and nations. They argue that homogenisation is positive as it promotes integration and the removal of cultural barriers. (Rothkopf [7]). But this process of dominant Western culture being transmitted globally results in changes to daily life based on Western values (Hsio [8]). Such a process, as claimed by non-Western scholars is based on unequal system of dominant control which is the real threat (Bennabi [9]). When Western culture has exerted its dominance pervasively, it stimulates cultural hegemony, and it undermines the cultural heritage of various peoples around the world (Muzaffar [10, pp. 5370]). Also, an imposition of values a hegemonic power not only generate 'sameness' in life styles, but also makes existing lifestyles, histories and traditions seem irrelevant and outmoded. The local cultures and diversity may be 
obliterated resulting in a homogenous mass culture (Muzaffar [10, p. 60]). The impact of globalisation due to explosion of information technology has shrunk geographical distances so that information about local happenings becomes shared with events that happens far away and vice versa (Waters [11]). But the content of global information, as argued by non-Western scholars, is controlled and dominated by the West which controls what others can watch and learn (Nurullah [3, p. 47]). For example, in world news, CNN and others, exert considerable control over what is telecast thus shaping the content and balance of global news materials. While scholars from non-Western countries agree on the positive impacts of advances in information technology (Annku and Adu-Agyem [2, p. 89]), they also acknowledge the dangers of showing films and television programs, which exhibit moral values which are in stark contrast to the more conservative values of people from non-Western countries (Tarabichi [12]).

\subsection{Positive adoptions of globalisation}

Be it as it may, globalisation is here to stay. It is a reality and a process which is now defined as the reality of the 21th century (Weibel [13]). There is no escaping from its impact and effects. But as many scholars have maintained, globalisation is a two-edged sword (Carden [14]. The only viable way forward is, to be able to think creatively and plan strategically on how to negotiate the positive elements and avoid its negativities. However, in Asia, three countries; China, South Korea and Japan for examples, have adapted, adopted and transformed their countries into developed nations as they have exploited the positive aspects of global processes to the utmost. They have succeeded in participating in globalisation yet still remain steeped in many aspects of their respective traditions. South Korea, in terms of culture for example, has become a global player in popular culture with spectacular success of 'K Pop' star - Psy's 'Gangnam' song and dance. The 'Gangnam' phenomenon brought 'K-Pop' to international attention and rivalled the popularity of America's Michael Jackson' So too the example of the visual art, of Chinese 'gunpowder' artist, Cai Guo-Qiang who uses gunpowder, deeply rooted in his own tradition, as his medium for creative expression. In this he reaffirm his cultural identity for global audiences. In similar vein, a renowned Malaysian artist, was inspired by the traditional craft of Malay weaving has been actively involved in asserting Malay Islamic identity to counter Western hegemony. The Malaysian artist is Sulaiman Esa.

\section{Sulaiman Esa: idea, art and creativity}

In the development of contemporary Malaysian art, Esa, now well known in Malaysia and abroad, has been consistent in his struggle to challenge cultural hegemony. Having grown up in the era of colonisation whose power came from Western imperialism, Esa, like Weibel [13], views colonisation as an aspect of globalisation. Cited by art critics and historians as one of the leading figures in the development of contemporary Malaysian art, Esa, was among the few Malaysian artists in the last five decades, who has struggled prominently and 
deeply to linking Eastern spirituality, modernism and the hegemony of Western aesthetics (Sharif [15]). Through his art, Esa has shown us how the sacred and the profane can co-exist with modernism and nationalism in contemporary sociopolitical, ethical and spiritual concerns. (Rajah [16, pp. 31-64]). Who is this artist? Where did he come from? Who influenced his thoughts and ideas? Why does he always strive to explore the unbeaten path to continuously assert his identity? Perhaps, the following paragraphs may provide answers to these questions.

\subsection{Sulaiman Esa: a brief biography}

Esa grew up in an artistically-inclined family where his interest in art was sparked by the work of his older siblings. More than twelve years of his life were spent in the West seeking formal training in art in London, an MFA in Baltimore, USA and a Ph.D. in Islamic studies at Temple University, Philadelphia, USA. While at Temple, he was deeply influenced by his renowned professors such as S.H. Nasr, the al-Faruqi's and M. Ayoub on Islamic thoughts and philosophy inclusive of studies of world religions. His prolonged exposures to the Western education system and social life-influenced in his thoughts and art after he returned to Malaysia in the late 1960s. His professional teaching career as a staff member, in the Fine Art Department of the Faculty of Art and Design, University Teknologi Mara (UiTM), lasted for more than four decades.

\subsubsection{Background in art and ideas}

Esa's approach to his artistic practice has always been intellectual. His formal art training at Hornsey, UK, emphasised analytical investigation in visual design, based on the Bauhaus tradition. It was coupled with a rigorous program in Liberal studies and deeply influenced his thoughts on art. Esa's intellectual horizon in understanding complex ideology in art activity, led him to being a "thinking artist," and according to Malaysian artist and art historian Piyadasa, can be attributed to the training he received at Hornsey (Piyadasa and Sabapathy $[17$, p. 136]). Esa's approach to art has always been shaped by the belief that, an artist is an arbiter, a mirror of his time, as advanced by sociologist, Hauser. An artist according to Hauser, must be consciously and actively responsive to the social and economic milieu that define his social reality if he is to remain relevant (Sanusi and Ahmad [18]). In the following text, we take a look at the artist's labyrinthine search for identity, from being immersed in Western-centric art in his youth to his later quest to find his cultural roots.

\section{Influence of Western-centric art}

The formal teaching in Western art was introduced by the British colonials in Malaya in the early $20^{\text {th }}$ century (Carline [19]). Its introduction in Malayan colonial schools in major cities along the Straits of Malacca, such as Singapore, Malacca and Penang, led to the birth of modern Malaysian art in 1930s (Piyadasa and Sabapathy [17, p. ix]). Before leaving for further studies in London in 1962, Esa was already familiar with Western art and its derivatives. 
He was deeply involved with the Impressionists' styles as seen in figure 1 'After Monet.' The dazzling effects of colours under different light intensity struck a chord in him. Later, it created a deep impact in his future art. When he returned home after six years, a reflection of Western-centric art is obvious in his Constructivist style as in figure 2 'Scroll No 6', emphasising on colour investigation. 'Colouristic painting' was considered as one of his significant contributions in 'colouristic painting' to Malaysian art tradition (Piyadasa and Sabapathy $[17$, p. 35]).

In Figure 3 'Man and his world' shows Esa's award-winning entry for the competition also named as 'Man and His World.' The objects displayed in 'Man and his world,' reflect the routines of Man's urban life style. Noteworthy is the

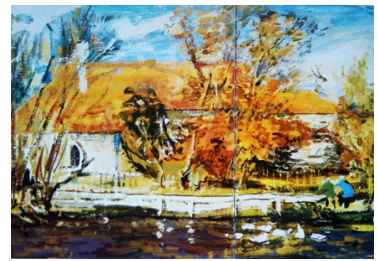

Figure 1: Sulaiman Esa, 'After Monet IV', Gouache, $50 \times 45 \mathrm{~cm}, 1961$. (Collection of the artist.)

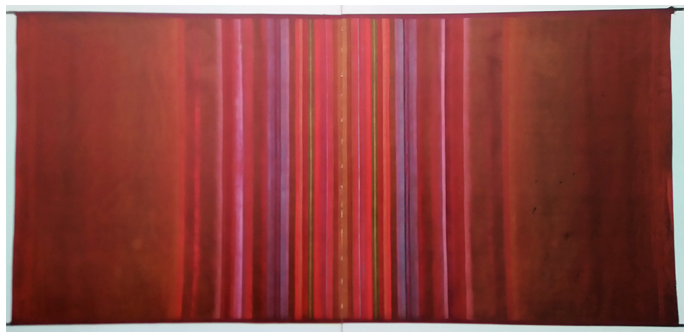

Figure 2: $\quad$ Sulaiman Esa, 'Scroll No. 6', Acrylic, 117×232 cm, 1971. (Source: collection of the artist.)

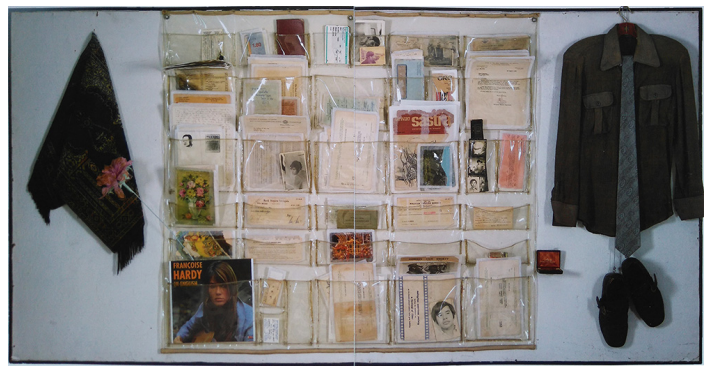

Figure 3: Sulaiman Esa, 'Man and His World', Mixed Media, $164 \times 247 \mathrm{~cm}$, 1972. (Source: National Art Gallery permanent collection.) 
suit and shoes on the right which might be seen as contrasting with the presence of a prayer rug hung on the left side, indicates that, deep inside, the Man is a Muslim!

\subsection{Rejection of dependence on Western art}

This manifesto was a response to the political situation in Malaya which gained Independence from Britain in 1957. The new independent government was committed to instilling Malay Islamic values in national culture (as a result to the race riots of 1969), through the convening of the 1971 National Cultural Congress (NCC) in which Malaysia's identity was spelled out in NCC's policy. The policy was: (i) elements of Malay art; (ii) the elements arts of other ethnic groups and iii) Islamic culture. The nation's assertion in upholding national identity in the post-colonial era was to counter the hegemony of Western culture in local art scene (Lovell [20]). Thus, in figure 4 'Toward a mystical Reality' a jointly-shared exhibit by Piyadasa and Esa's attempt in liberating Malaysian artists' dependence on Western influences and replacing it with an Eastern tradition: the Zen and Buddhist perspectives in the appreciation of reality.

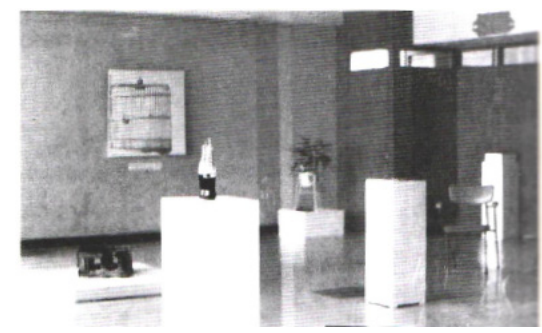

Figure 4: $\quad$ Piyadasa and Esa, 'Towards a Mystical Reality', mixed media 1974. (Source: National Art Gallery permanent collection.)

\subsubsection{Esa: at the crossroads}

After effectively rejecting Western-centric art, Esa was in an impasse. However, it was during this period he produced a controversial piece figure 5 'Waiting for Godot'- his 'self-portrait.' After negating Western art, he slowly came to terms with his Islamic roots. During the post-colonial period, Esa was confronted with complex questions of to how to reconcile Islamic elements with Malaysian Nationalism, Islam and Modernism. In the multi-ethnic society of Malaysia, is he a Malay, a Muslim or a Malaysian? It is within this soul-searching period that he produced the above-mentioned work. The nude symbolises his Westernised-self, while the mosque architecture represents Islam. The images derive from magazines bought in Rome and to him they are poetic and not even sexy. Controversial as the work was, he won an award in the 'Printmaking Competition' organised by the National Art Gallery (Rajah [16, p. 35]). 


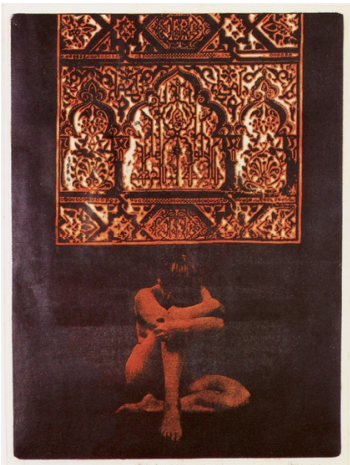

Figure 5: Sulaiman Esa, 'Waiting for Godot', Silkscreen, 76×62 cm, 1977 . (Source: National Art Gallery permanent collection.)

\subsection{Transforming craft as art}

In response to the NCC policy, and realising the critical need to get back to his roots, Esa felt committed to uplifting traditional Malay art to the special status, it once enjoyed. To do so, he deliberately employed Malay decorative patterns in figures 6 and 7, to subvert the Western art model which prioritises iconographic expression as a superior form of art. Esa draws on traditional Malay aesthetic

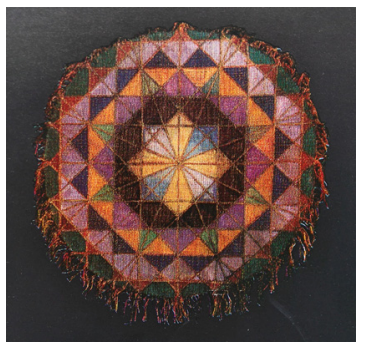

Figure 6: Sulaiman Esa, 'Nurani 1', acrylic, handmade paper, yarn, $140 \times 140 \mathrm{~cm}, 1983$. (Source: collection of the artist.)

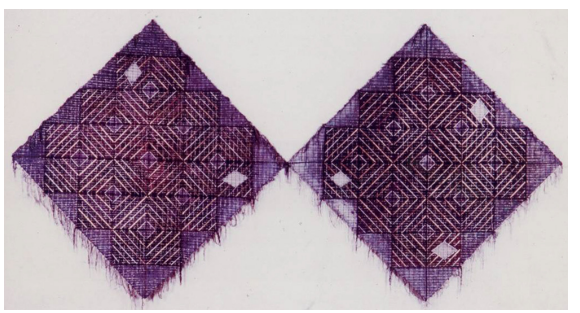

Figure 7: Sulaiman Esa, 'Jamal and Jalal', mixed media, 1984. (Source: collection of the artist.) 
tradition because it provides spiritual significance embodying Islamic ideology in the external features of traditional Malay art forms; be they in geometry, arabesque, and calligraphy, all the elements are intrinsically pleasing enhanced with colours that are attractive to the eyes (Coombes [21]).

\subsection{Early Islamic period: spiritual awakening}

Among the salient points discussed in this period was Esa's preoccupation with the 'garden mystery' series developed after pursuing his Ph.D. in Islamic studies at Temple U., under world-renowned Muslim scholars. It was a spiritual awakening to him.

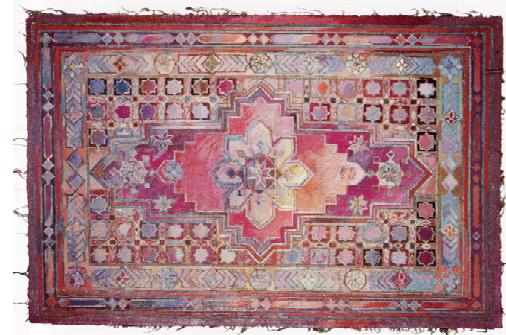

Figure 8: Sulaiman Esa, 'Garden of Mystery IV', mixed media, $216 \times 157 \mathrm{~cm}$, 1992. (Source: National Art Gallery permanent collection.)

For example, in figure 8 'Garden of Mystery IV' is his interpretation of the deep nostalgia for paradise reflected in 'the other world beauty,' an influence from Sufism. In this work he represents the symbolic space of carpet with all the inherent intimations of expansion, ascension, of man's essential being in time and space.

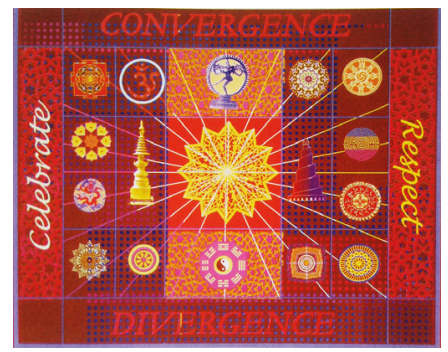

Figure 9: Sulaiman Esa, 'Convergence and Divergence II', digital print $37 \times 45 \mathrm{~cm}, 2000$. (Source: collection of the artist.)

Figure 9 'Convergence and Divergence II', is Esa's interpretation of people living in diverse cultures as in Malaysia, yet staying united and living in harmony through respect. In accord with Qur'anic teaching, there is celebration when there are differences as well as when there are similarities. 


\subsubsection{Universal values of Islam: retrospective exhibition 2011}

Central to this retrospective exhibit (see figure 10), was Esa's socio-critical response to the September 11 disaster in New York.

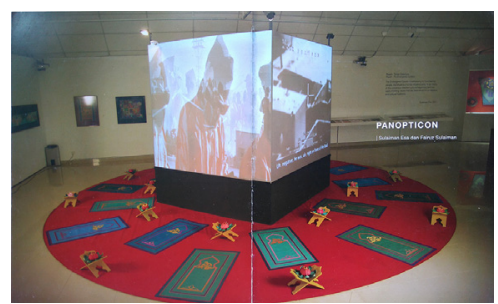

Figure 10: Sulaiman Esa, Fairuz Sulaiman, Panopticon, video installation, $274 \times 731.5 \times 731.5 \mathrm{~cm}, 2011$. (Source: collection of the artist.)

A jointly produced work with Fairuz Sulaiman, the installation unfolds his interpretations of the Western superpowers' fears of Muslim countries after the tragedy. It is based on the model for prison designed by J. Bentham (1748-1832) in which, cells are in a circular form in order to scrutinise the prisoners' activities from a central watch tower where their movements are constantly monitored using spotlights. In the installation, each side of the cube carries one of four video images of Muslim prisoners in contemporary Iraq.

\section{Findings: the significance of Esa's art in contemporary Malaysian and Asian art}

\subsection{Embarking on a paradigm shift: weaving as replacement of canvas}

Esa's commitment to exploring indigenous natural materials as a base surface to art, is considered a milestone in the development of the contemporary Malaysian art scene (Faruqi [22]; Chuen [23]; Shunmugam [24]). He embarked upon an alternative direction in creating art purely from indigenous materials and local techniques to avoid dependence on western technique. In so doing, he also adopted traditional Malay aesthetic principles such as refinement, balance, structure, symbolism and function as in figure 11 'Mahsuri II' is inspired by the 'kepala kain' (main design) of a sarong, decorated with bamboo shoot motifs in striking colours employing Malay aesthetic principles with colourful ornamentations as the core of the spiritual expression embedded in the final form of the art. Uniting symbols with sophisticated patterns, Esa has the ability to extend the boundaries with flexible surfaces uplift Malay craft into art into a uniquely visual expression (Frederich [25]). 


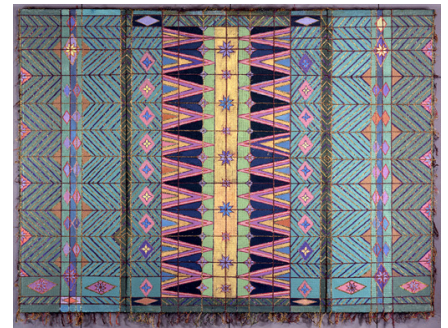

Figure 11: Sulaiman Esa, 'Mahsuri II', mixed media, $181 \times 298.5 \mathrm{~cm}, 1983$. (Source: collection of Fukuoka Museum, Japan.)

\subsection{Transcending the dichotomy between art and crafts}

His deliberate attempt to reject the dichotomy between art and craft was made possible by revitalising craft as art, a status it once enjoyed before colonisation. Craft plays a significant role in Malay society as it is embedded with a spiritual basis whose decorative ornamentations is not purely decorative but spiritually enriching to the souls of those who came in contact with it.

\subsection{Social and spiritual dimensions}

Esa's interpretation of the Qur'anic surah al-Hujarat, verse: 13:'We have created you into nations and tribes, that ye know each other ... the most honoured of you among the sight of Allah is (he who is) the most righteous of you. Ali [26] is particularly relevant in the context of the current racial and political conflicts the world is facing now. His interpretations of this verse as in figure 9, calls global attention to humans living in diverse cultures to strive for racial harmony. $\mathrm{He}$ believes that postcolonial artists must challenge colonial legacies, as the creation of ethnic diversity, was a divine intention.

\subsubsection{Embarking for an alternative paradigm in the expression of contemporary Islamic-inspired art in Southeast Asia}

Western scholars seem to focus on Islamic art from Spain, the Middle East and India only. Very little has been written on Islamic art from beyond India, let alone from Southeast Asia. Some scholars even insist that Islamic art beyond India does not exist. However, anthropologist Professor Kenneth George maintains that both A. D. Pirous (from Indonesia) and Esa, have continuously spent their creative pursuits in Islamic inspired art for more than five decades. They have pioneered a new direction in the development of contemporary Islamic art not only in their respective countries but also in the Southeast Asian region (George [27]).

\section{Conclusion}

From the above writing, it is obvious that globalisation has both its positive and negative effects. Given a properly planned strategy, its negativity could be 
overcome while its benefits and potentials could be exploited to the utmost. In the case of Esa, he has dialectically responded to the challenges of globalisation by foregrounding and adopting his Malay Islamic Asian tradition, while avoiding secular values. This is possible because of his continuous explorations of the unlimited opportunities for artistic expression provided by global information technology in terms of new media, techniques, socio-cultural and political events worldwide. Hence, Esa is able to produce unique works embodying Southeast Asian cultural traditions expressed in contemporary artistic modes. He has represented his nation and has been invited to many art-related activities locally and internationally - intellectual discourses, art biennales, triennials - and his works are represented in museums and art galleries, in a number of Southeast Asian countries, Japan, Australia, Singapore and the United States to name a few. All this is testimony to Esa's work as relevant, unique and originally Asian. He has thrived on responding to globalisation!

\section{References}

[1] Tabb, W.K. Globalisation. Redmond, WA: Microsoft Corporation, p. 2, 2009.

[2] Annku, M.F. \& Adu-Agyem, J. "The impact of globalisation on the Arts in contemporary Ghana." Ghana Mining Journal, 2012.

[3] Nurullah, A.S. "Globalisation as a challenge to Islamic cultural identity." The International Journal of Interdisciplinary Social Silences, Melbourne: Common Ground Publishing, Vol. 3, No. 6, 2008.

[4] Waters, M. Globalisation (2nd ed.). London and New York: Routledge, 2001.

[5] Vertigans, S., \& Sutton, P.N. "Globalisation theory and Islamic praxis." Global Society, 16(1), pp. 31-46, 2002.

[6] Mazrui, A.A. "Globalisation from the Islamic perspective." Speech delivered at Forum on Islam and Globalisation, Westminister University, London, 2000.

[7] Rothkopf, D. "In praise of cultural imperialism?” In J.F. Harf \& M.O. Lombardi (Eds.), Taking sides: Clashing views on controversial global issues. Guilford, CT: McGraw-Hill, pp. 284-293, 2004.

[8] Hsio, "Coexistence and synthesis: cultural globalisation and localisation in contemporary Taiwan.” In P.L. Berger \& S.P. Huntington (Eds.), Many globalisations: cultural diversity in contemporary world. New York: Oxford University Press, pp. 48-67, 2003.

[9] Bennabi, M. The question of culture (tr. Abdul Wahid Lu'lu'a). Petaling Jaya and Surrey: Islamic Book Trust and IIIT, 2003.

[10] Muzaffar, C. "Challenges of the 21st. Century: Islamic responses and the role of the Muslim artist." In J. Ali, K. Sanusi, R. Basaree, eds., Semurni, vol. 1/97, Shah Alam: KSSR Press, 1997.

[11] Waters, M. Globalisation (2nd ed.). London and New York: Routledge, 2001. 
[12] Tarabichi, G. From Arab renaissance to apostasy: Arab culture and its discontents in the age of globalisation. London, Beirut: Sagi Books, 2000.

[13] Wiebel, P. “Globalisation: The end of modern art?" ikono(http://ikono.org/ 2013/07/globalisation-the-end-of-modern-art/) accessed on 10/01/2016.

[14] Carden, A. "Does globalisation destroy culture?" The Independent Institute.

[15] Sharif, Z.A. "Forward." In N. Rajah, ed. Insyirah The art of Sulaiman Esa from 1980-2000,' Kuala Lumpur: Petronas, p. 10, 2001.

[16] Rajah, N. "Insyirah Al Sadr: The art of Sulaiman Esa." In N. Rajah, ed. Insyirah: The Art of Sulaiman Esa from 1980-2000. Kuala Lumpur: Petronas, pp. 31-64, 2001.

[17] Piyadasa, R. \& Sabapathy, T. K. Modern artists of Malaysia. Kuala Lumpur: DBP, 1983.

[18] Sanusi, K. \& Ahmad, F. R. From the periphery to the Centre: The social significance of Sulaiman Esa's work from 1950s-2007. Unpublished research sponsored by Research Institute UiTM, Shah Alam, p. 4, 2010.

[19] Carline, R. Draw they must. Chatham: W. \& J. Mackay, p. 114, 1986.

[20] Lovell, J. Malay artists and the Malaysian Cultural Congress: Three case studies. Unpublished thesis, School of Humanities, Australian National University, p. 89, 2004.

[21] Coombes, H. A. "The Islamic spirit: Social orientation on contemporary Malaysian art." In H. Ahmad, ed. Art \& Spirituality. Kuala Lumpur; National Art Gallery, pp. 17-29, 1995.

[22] Faruqi, L. "Islamic literary principles and the visual arts: Case study from Malaysia." Paper for Seminar on Islamic art, sponsored by Dewan Bahasa dan Pustaka, Kuala Lumpur, 1984.

[23] Chuen, O.K. “On a spiritual quest.” New Straits Times, Feb. 19, 2001.

[24] Shunmugam, V. "Building bridges to promote unity." Sunday STAR, March, 2001.

[25] Frederich, H.C. "Works on paper." Travelling show catalogue Baltimore, USA: Maryland State Arts Council, 1981.

[26] Ali, Y. (1985). The Holy Qur'an. Madinah: Dept. of Islamic Research.

[27] George, K. M. Picturing Islam: Art and ethics in a Muslim lifeworld. West Sussex, UK: Wiley-Blackwell, 2012. 